\title{
DETEKSI MOLEKULER TIALPIA LAKE VIRUS (TILV) PADA IKAN NILA (Oreochromis niloticus) YANG DILALULINTASKAN DI BALAI BESAR KIPM JAKARTA I.
}

\author{
Khaerul Jamal, Firsty Rahmatia, Yudha L. Dhewantara \\ Fakultas Perikanan dan Ilmu Kelautan \\ Universitas Satya Negara Indonesia
}

\begin{abstract}
Abstrak
Ikan nila (Oreochromis niloticus) merupakan komoditas unggulan budidaya air tawar di Indonesia ketiga tersebsar setelah udang dan rumput laut. Virus TiLV pertama kali ditemukan melalui studi kematian massal ikan nila (Oreochromis niloticus) di Danau Kinneret, Israel. Kasus kematian massal ikan nila terjadi di beberapa lokasi budaya di Jawa, Lombok, dan Sumatera yang disebabkan oleh infeksi Orthomyxovirus (TiLV). Tujuan penelitian ini adalah untuk mendeteksi adanya infeksi TiLV dengan metode semi-nested Reverse Transcriptase-Polymerase Chain Reaction (RT-PCR pada sampel yang dilalulintaskan melalui Balai Besar KIPM Jakarta I. Lokasi pengambilan sampel di Bogor, Jakarta, Sukabumi dan Tangerang. Analisis deteksi RT-PCR menggunakan sampel organ otak, ginjal, limpa, dan hati. Hasil pengamatan terhadap gejala klinis terhadap ikan nila Normal, dan infestasi penyakit 0\%. Hasil analisis RT-PCR menunjukkan Negatif Tilapia Lake Virus (TiLV).
\end{abstract}

KATA KUNCI: nila; TiLV; seminested RT-PCR.

\begin{abstract}
Tilapia (Oreochromis niloticus) is the third leading commodity in freshwater cultivation in Indonesia, after the shrimp and seaweed. The TiLV virus was first discovered through a study of the mass death of tilapia (Oreochromis niloticus) on Lake Kinneret, Israel. . Cases of tilapia mass death occur in several cultural locations in Java, Lombok, and Sumatra caused by Orthomyxovirus (TiLV) infection. The purpose of this study was to detect the presence of TiLV infection using a semi-nested Reverse TranscriptasePolymerase Chain Reaction method (RT-PCR) in samples that were crossed through the KIPM Jakarta Central Office I. Sampling locations in Bogor, Jakarta, Sukabumi and Tangerang. RT detection analysis The PCR used samples of brain, kidney, spleen, and liver organs, and the results of observations on clinical symptoms of Normal tilapia and $0 \%$ disease infestation The RT-PCR analysis showed negative Tilapia Lake Virus (TiLV).
\end{abstract}

KEYWORDS: indigo; TiLV; Seminested RT-PCR

\section{PENDAHULUAN}

Ikan nila (Oreochromis niloticus)

pertama kali masuk ke Indonesia sebagai ikan introduksi pada tahun 1969 dan tersebar di Danau Tempe, Sulawesi Selatan (Nugroho, 2013). Ikan nila merupakan salah satu komoditas unggulan untuk budidaya air tawar di Indonesia dengan tingkat produksi yang terus meningkat. Produksi ikan nila tingkat nasional pada tahun 2010 tercatat sebesar 464.191 ton, dan naik menjadi 999.695 ton pada tahun 2014 (KKP, 2015).

Virus TiLV pertama kali ditemukan melalui studi kematian massal ikan nila (Oreochromis niloticus) yang terjadi di Danau Kinneret, Israel, (Eyngor et. al, 2014). Virus tersebut kemudian menyebar ke negara lain secara cepat sehingga pada tahun 2017 negara yang telah terkonfirmasi terkena wabah virus TiLV pada ikan nila meliputi Israel sebagai negara awal wabah, Mesir, Ekuador, Kolombia dan 
Thailand (FAO 2017).

Virus ini merupakan genus dari famili Orthomyxoviridae, yang mereplikasi di inti sel pada jaringan ikan. TiLV yang pertama kali dilaporkan terjadi di Israel menyebar ke Ekuador dan Kolombia (Eyngor et al., 2014; Bacharach et al., 2016) dan ke beberapa negara seperti Mesir (Fathi et al., 2017 dan Nicholson et al., 2017), Thai-land (Dong et al., 2017a; 2017b; Surachetpong et al., 2017), serta India (Behera et al., 2017), serta Malaysia (Amal et al., 2017). Di Indonesia sejak beberapa tahun belakangan ini sering terjadi adanya kasus kematian massal budidaya ikan nila terutama di Sumatera, Jawa, Bali, dan Lombok. Walaupun belum diketahui penyebab kematiannya, namun bila dilihat dari gejala klinis yang terlihat kemungkinan disebabkan oleh adanya infeksi virus TiLV.

\section{BAHAN DAN METODE}

Metode uji untuk pengujian

Tilapia Lake Virus (TiLV) adalah Real- Time PCR dan PCR Konvensional Nested PCR. Pengambilan contoh uji dalam penelitian Tilapia Lake Virus (TiLV)idasarkan pada frekuensi kegiatan lalulintas ikan nila antar area melalui Balai Besar KIPM Jakarta I. Penelitian ini dilaksanakan di Laboratorium Balai Besar KIPM Jakarta I dimulai dari bulan Mei 2018 sampai Juli 2018.

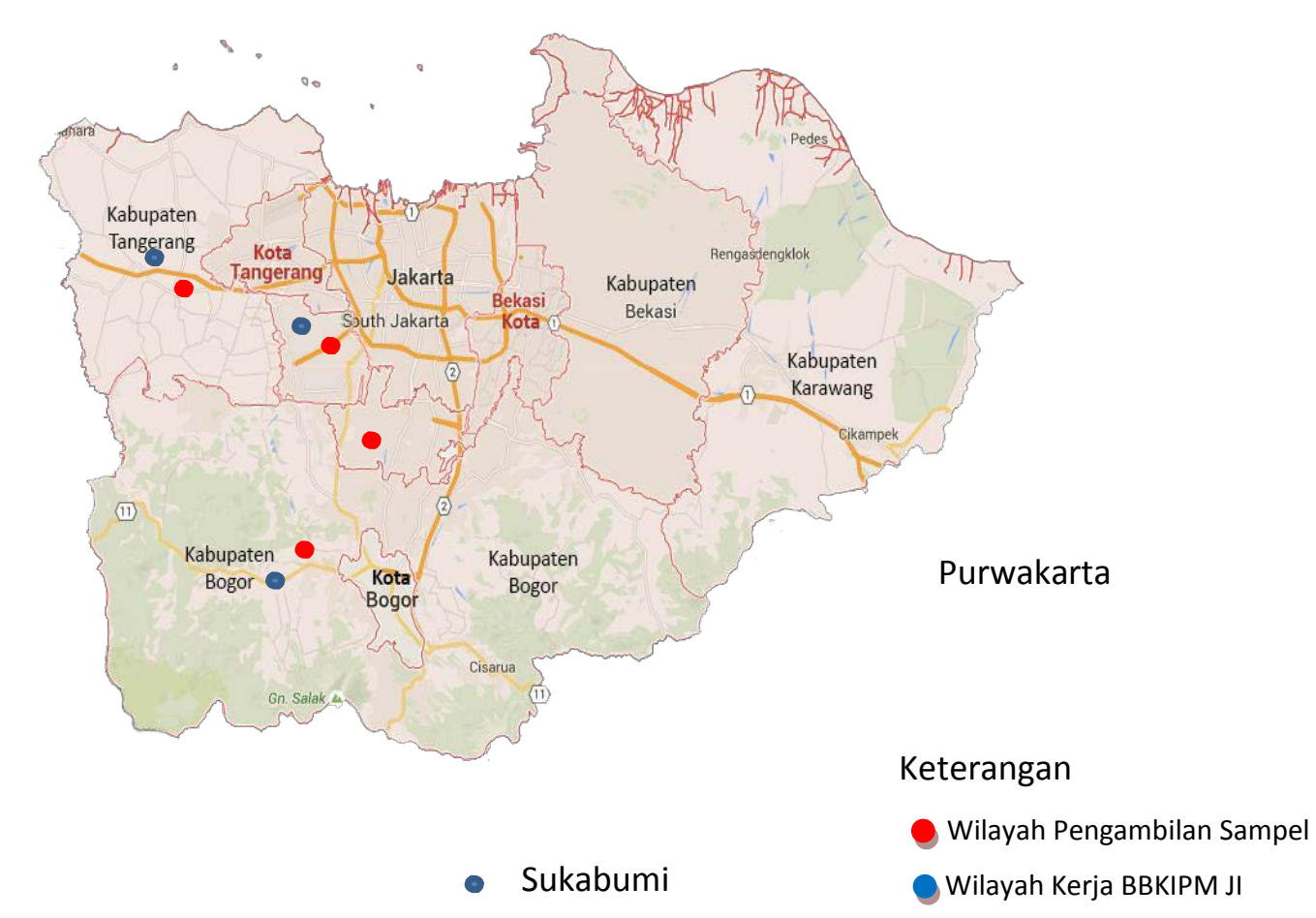

Gambar 1. Peta wilayah kerja Balai Besar KIPM Jakarta I (BBKIPM JI.2017). 
Alat-alat yang digunakan dalam penelitian ini adalah : Alat pengukur konsentrasi RNA berbasis spektrofotometri UV, freezer $\left(-20^{\circ} \mathrm{C}\right.$ atau lebih rendah), heating block atau waterbath, laminar flow, mesin real time PCR, mini mixer, mikropipet berbagai ukuran $0,1 \mu \mathrm{l}-1000 \mu \mathrm{l}$, alat bedah pinset dan gunting, sentrifius, mini sentrifius, peralatan gelas, timbangan analitik dengan ketelitian 0,1 $\mu \mathrm{g}$. Bahanbahan yang digunakan dalam penelitian ini adalah : Buffer tris EDTA, nuclease-free water, etanol, filtered microcip berbagai ukuran $0,1 \mu \mathrm{l}-1000 \mu \mathrm{l}$, isopropanol, kloroform, kit real-time PCR, larutan ekstraksi DNA, larutan penghambat DNAse, masker, penggerus jaringan, plasmid standar positif Tilapia Lake Virus (TiLV), sarung tangan, 1 set primer dan probe, tabungan mikro ukuran $0,2 \mathrm{ml}, 1,5 \mathrm{ml}-2 \mathrm{ml}$, tabungan atau microplate PCR optikal ukuran 0,1 $\mathrm{ml}-0,2 \mathrm{ml}$ atau tabungan kapiler ukuran $20 \mu \mathrm{l}-100 \mu \mathrm{l}$.

Sampel uji diambil dari beberapa pelaku usaha dan daerah sebar di wilayah kerja Balai Besar KIPM Jakarta I, yaitu Bogor, Jakarta, Sukabumi dan Tangerang. Disetiap lokasi diambil sampel ikan sebanyak 18 ekor. Sampel ikan diambil organ target untuk pengujian yaitu ginjal dan limpa kemudian di ekstraksi RNA, amplifikasi RNA untuk mengetahui hasil pengujian.

\section{HASIL DAN PEMBAHASAN}

Dari Hasil Pengujian sampel Ikan Nila yang di ambil dari empat wilayah berbeda, meliputi Sukabumi, Jakarta, Tangerang dan Bogor didapat hasil pengujian yang menunjukan Negatif Tilapia Lake Virus (TiLV). Dari hasil uji terhadap sampel yang ada baik pada fist step dengan 415 bp maupun pada semi nested dengan 250 bp tidak menunjukkan hasil yang signifikan terhadap munculnya Tialpia Lake Virus $(T i L V)$.

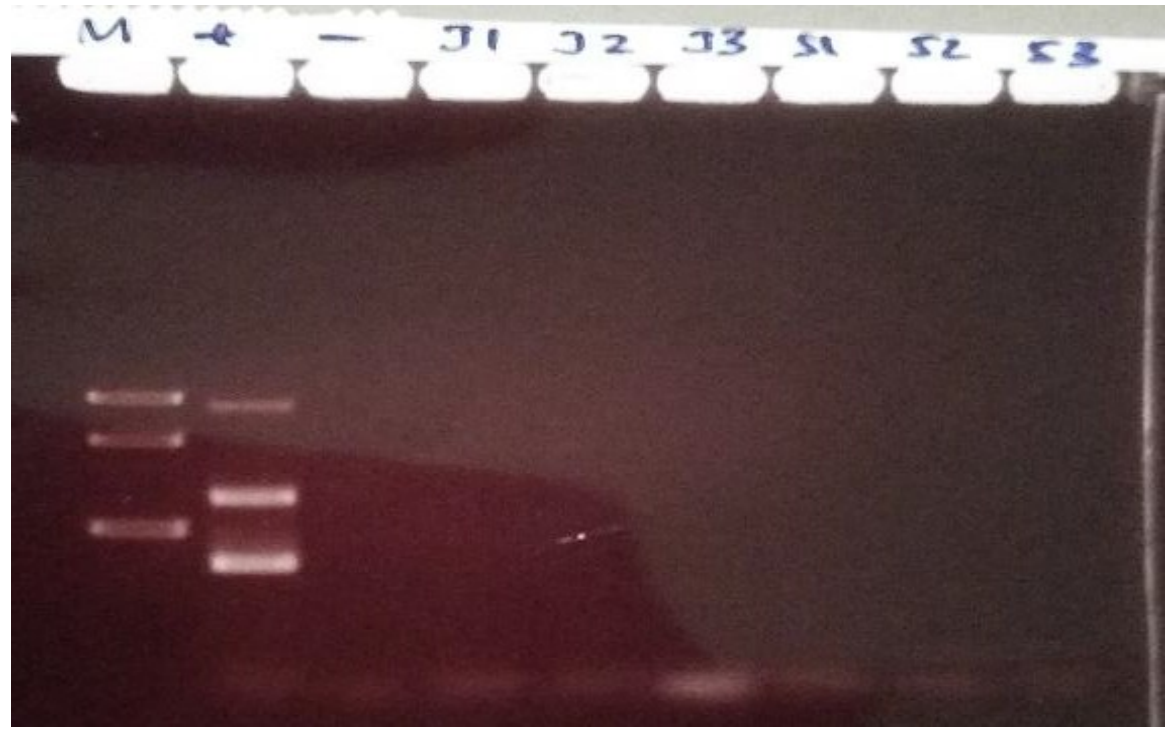

Gambar 2. Hasil foto elektroforesis terhadap sampel ikan (Marker 100 bp, J:Jakarta, S : Sukabumi) 
Analisis pengujian TiLV menggunakan dobel step karena materi sampel yang di uji merupakan jaringan RNA. Analisis semi-nested selanjutnya dilakukan untuk menentukan lebih pasti ada tidaknya organ yang terpapar oleh TiLV, mengingat metode tersebut dapat meningkatkan sensitivitas deteksi. Pada first step PCR amplikon yang dielektroforesis dikatakan positif jika terbaca atau terdapat pita tunggal pada 415 bp dan untuk nested PCR dikatakan positif jika terbaca atau terdapat pita tunggal pada 250 bp hal ini menunjukkan nila (Oreochromis niloticus) yang diuji bebas dari serangan Tilapia Lake Virus (TiLV).

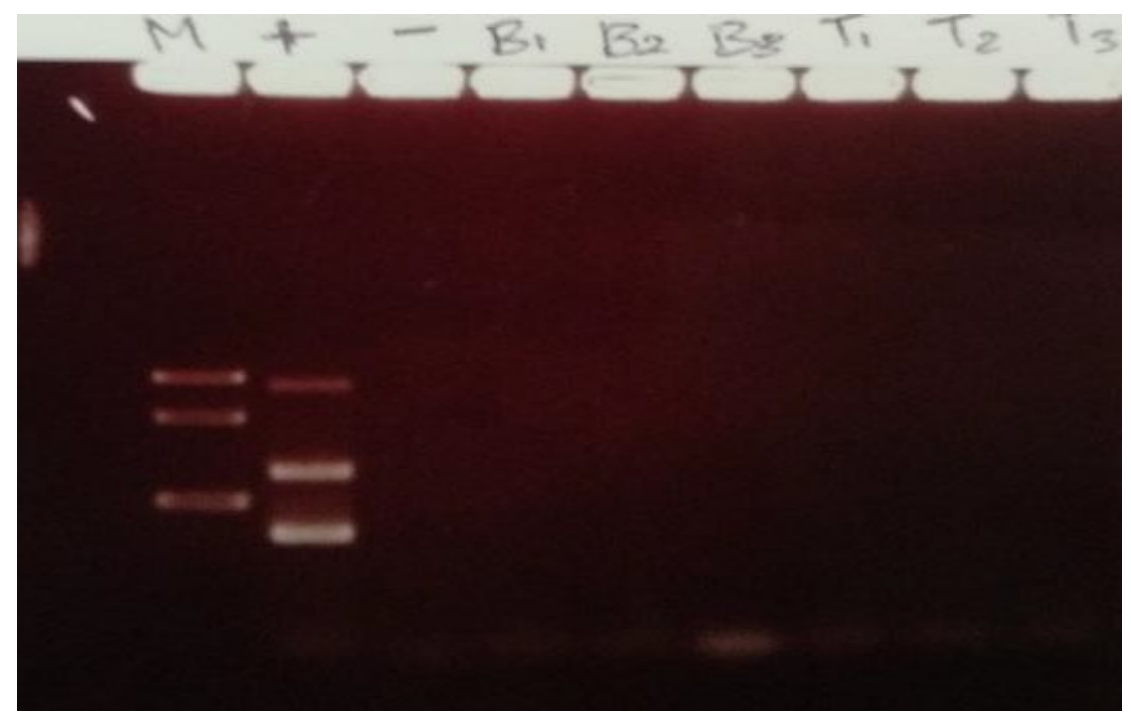

Gambar 3. Hasil foto elektroforesis terhadap sampel ikan (Marker 100 bp, B:Bogor, T : Tangerang)

Dengan hasil analisis molekuler menggunakan semi-nested Real Time PCR menunjukkan bahwa kematian ikan nila (Oreochromis niloticus) yang terjadi secara suspektif disebabkan oleh banyak faktor dan belum tentu karena adanya infeksi TiLV. Pada target berat molekul 415 bp menunjukkan bahwa ikan nila negatif terinfeksi $T i L V$, sedangkan pada infeksi ringan DNA hasil amplifikasi juga tidak terlihat pada berat molekul 250 bp. Parameter kedua yang diamati adalah infestasi pada sampel ikan nila (Oreochromis niloticus). Persentase infestasi nila (Oreochromis niloticus) yang terserang penyakit Tilapia Lake Virus (TiLV) sampel dari Jakarta sebesar $0 \%$, Tangerang sebesar $0 \%$, Bogor sebesar $0 \%$, dan Sukabumi sebesar $0 \%$, ini berarti indikasi ikan yang terserang penyakit tidak ada. Data infestasi sesuai Tabel 10 tidak ditemukan indikasi sampel ikan yang terserang Tilapia Lake Virus (TiLV).

Parameter ketiga yang diamati adalah gejala kinis dan tingkah laku sampel ikan. Sampel ikan nila (Oreochromis niloticus) yang di amati menunjukkan gejala normal pada hari pertama, ikan secara umum ikan berenang normal dan nafsu makan sedikit menurun pada hari pertama, hal ini karena sampel ikan mengalami proses adaptasi dan stress diperjalanan dari tempat pengambilan sampel ke Aquarium Laboratorium uji.

Secara umum kondisi ikan normal dengan gerakan yang lincah dan nafsu makan yang tidak mengalami penurunan. Secara fisik juga tidak terlihat kerusakan pada organ mata dan insang serta sisik ikan. Hal ini berbeda dengan ciri umum jika ikan terindikasi terserang Tialpia Lake Virus (TiLV). Adanya kematian pada sampel ikan yang diamati di anggap normal sebagai akibat dari stress dari lamanya perjalanan sampel ikan dari tempat pengambilan sampel ke labatorium pengujian. Hal ini terlihat dari gerakan ikan pada saat sampai di laboratorium dan respon terhadap pakan yang 
diberikan. Selain itu tanda-tanda kematian ikan juga tidak menunjukkan gejala klinis yang mengarah ke TiLV.

Perkembangan $\quad T i L V$ sangat dipengaruhi oleh lingkungan, dimana Indonesia yang memiliki iklim tropis yang sangat kondusif bagi perkembangan TiLV. Wabah yang terjadi di Ekuador terjadi sepanjang tahun dimana suhu air berkisar antara 25$27^{0} \mathrm{C}$, akan tetapi wabah yang terjadi di Israel terjadi pada musim panas (Mei sampai Oktober; suhu $22-32^{0} \mathrm{C}$ ), hal tersebut menunjukan bahwa penyakit ini musiman dan faktor suhu berperan penting dalam terjadinya wabah (Sunarto dan Mc.Coll, 2016). Faktor pemicu timbulnya wabah penyakit TiLV adalah suhu air dan kepadatan tinggi. Suhu air Berdasarkan hasil pengukuruan kualitas air yang disajikan pada Tabel 4 diperoleh suhu rata-rata di daerah Jakarta, tangerang, Bogor dan Sukabumi berkisar antara $24-30^{\circ} \mathrm{C}$.

Kisaran suhu tersebut sesuai dengan standar suhu untuk pemeliharaan ikan nila (Oreochromis niloticus) sebesar $28{ }^{\circ} \mathrm{C}$. Kenaikan suhu akan meningkatkan kebutuhan energi pemeliharaan dan ikan akan lebih aktif dalam mencari makanan. (Goddard, 1996).Nilai pH yang mampu ditoleransioleh ikan nila berkisar antara 6 - 9, tetapiyang menyebabkan wabah terjadi di atas $25^{\circ} \mathrm{C}$, suhu yang tidak menyebabkan kematian adalah dibawah $20^{\circ} \mathrm{C}$, dan puncak kematian masal terjadi pada suhu $30^{\circ} \mathrm{C}$ (Tsofack et al., 2017).

Wabah TiLV diberbagai negara Secara klinis telah dilaporkan terjadi selama musim panas, yaitu Mei hingga Oktober (pada suhu air $22^{0} \mathrm{C}$ hingga $32^{\circ} \mathrm{C}$ ) di Israel (Eyngor et al. 2014), Juni hingga Oktober $\left(\geq 25^{\circ} \mathrm{C}\right)$ di Mesir (Fathi et al. 2017) hingga November $\left(25^{0} \mathrm{C}\right.$ hingga $\left.27^{\circ} \mathrm{C}\right)$ di Ekuador (Ferguson et al. 2014). Beberapa sampel yang menghasilkan deteksi TiLV positif di Thailand dikumpulkan pada bulan antara bulan Oktober dan Mei (Surachetpong et al. 2017).

untuk pertumbuhan dan perkembangan yang optimal berada pada kisaran $\mathrm{pH} 7$ 8. Adapun nilai DO yang diperoleh dari pengukuran kualitas air dari ke empat wilayah pengambilan sampel diperoleh nilai berkisar antara 5,2-7,6 ppm. Oksigen terlarut dalam air merupakan faktor penting bagi kehidupan ikan karena oksigen dibutuhkan dalam proses pernapasan dan merupakan komponen utama bagi metabolisme ikan (Wardoyo, 1975).

\section{KESIMPULAN DAN SARAN}

Berdasarkan hasil penelitian ini dapat disimpulkan bahwa tidak terdeteksi sampel nila (Oreochromis niloticus) yang terserang oleh Tilapia Lake Virus (TiLV). Infestasi pada sampel ikan nila (Oreochromis niloticus). Persentase infestasi nilai (Oreochromis niloticus) yang terserang penyakit Tilapia Lake Virus (TiLV) sampel dari Jakarta sebesar0 \%, Tangerang sebesar $0 \%$, Bogorsebesar $0 \%$, dan Sukabumi sebesar $0 \%$, ini berarti indikasi ikan yang terserangpenyakit tersebut tidak ada. Pada pengamatan gejala klinis baik dari segi fisik, tingkah laku dan nafsu makan ikan yang relatif normal.

Sesuai hasil pemeriksaan klinismaupun laboratoris tidak ditemukan sampel nila (Oreochromis niloticus) yang terserang oleh Tilapia Lake Virus (TiLV) namun tetap harus jadi perhatian serius mengingat Indonesia merupakan penghasil budidaya Ikan Nila terbesar kedua di dunia. Selain itu Pelaksanaan proses budidaya dan penggunaan indukmaupun benih nila (Oreochromis niloticus) impor yang berasal dari negara yang mengalami kasus Tilapia Lake Virus(TiLV) harus di waspadai termasuk penggunaan pakan dalam budidaya nila (Oreochromis niloticus). 


\section{UCAPAN TERIMAKASIH}

Terimakasih disampaikan kepadaLaboratorium Balai Besar KIPM Jakarta I yang telah memberikan fasilitas pengujian dan analisis hingga tersusunnya Skripsi ini. Terimakasih juga disampaikan kepada Ibu Firsty Rahmatia dan Bpk Yudha Lestari Dhewantara atas bimbingan dan masukannya.

\section{DAFTAR PUSTAKA}

Amal, M.N.A., Koh, C.B, Nurliyana, M., Suhaiba, M., Nor-Amalina, Z., Santh, S., Diyana-Nadhirah, K.P., Yusof, M.T., Ina-Salwany, M.Y., \& Zamri-Saad, M. 2017. A case of natural co-infection of Tilapia Lake Virus and Aeromonas veronii in a Malaysian red hybrid tilapia (Oreochromis niloticus $\mathrm{x} O$. mossambicus) farm experiencing high mortality. Aquaculture, 485, 12-16

Bacharach, E., Mishra, N., Briese, T., Zody, M.C., Kembou Tsofack, J.E., Zamostiano, R., \& Lipkin, W.I. 2016. Characterization of a Novel Orthomyxo-like Virus Causing Mass Die-Offs of Tilapia. MBio, 7, 1-7.

Badan Karantina Ikan Pengendalian Mutu.

2017. Keputusan Kepala Badan Karantina Ikan Pengendalian Mutu dan Keamanan Hasil Perikanan Penetapan Tilapia Lake Virus (TiLV) Sebagai Penyakit Ikan Yang Dicegah Pemasukannya Kedalam Wilayah Negara Republik Indonesia. Jakarta

Dong HT, Ataguba P, Khunrae T, Rattanarojpong T and Serapin S. 2017b. Evidence of TiLV infection in tilapia hatcheries in Thailand from 2012 to 2017a reveals probable.

Dong HT, Siriroob S, Meemetta W, Santimanawong W, Gangnonngiw W, Pirarat N, Khunrae P, Rattanarojpong T, Vanichviriyakit R and Senapin S. 2017a. Emergence of Tilapia Lake Virus in Thailand and an alternative seminested RT-PCR for detection. Aquaculture 476:111-18.

Eyngor M, Zamostiano R, KembouTsofack JE, Berkowitz A, Bercovier H, Tinman S, Lev M, Hurvitz A, Galeotti M, Bacharach E et al. 2014. Identification of a novel RNA virus lethal to tilapia. Journal of Clinical Microbiology 52:4137- 46. doi: $\quad$ 10.1128/JCM.00827-14.

Epub 2014 Sep 17.

Eyngor M, Zamostiano R, KembouTsofack JE, Berkowitz A, Bercovier H, Tinman S, Lev M, Hurvitz A, Galeotti M, Bacharach E et al. 2014. Identification of a novel RNA virus lethal to tilapia. Journal of Clinical Microbiology 52:413746.

Fathi M, Dickson C, Dickson M, Leschen W, Baily J, Muir F, Ulrich K and Weidmann M. 2017. Identification of Tilapia Lake Virus in Egypt in Nile tilapia affected by ‘summer mortality’ syndrome. Aquaculture 473:430-32.

Ferguson HW, Kabuusu R, Beltran S, Reyes E, Lince JA and del Pozo J. 2014. Syncytial hepatitis of farmed tilapia, Oreochromisniloticus (L.): A case report. Journal of Fish Diseases 37:583-89.

Food and Agriculture Organization. 2017.

Outbreaks of Tilapia Lake Virus (TiLV) Threatens the Livelihoods and Food Security of Millions People Dependent on Tilapia Farming. 
Goddard, S. 1996. Feed Management in Intensive Aquaculture. Chapman and Hall, New York.

Harrysu, 2012. Budidaya Ikan Nila (Oreochromis niloticus) . Kasinius: Yogyakarta.

Kementerian Kelautan dan Perikanan. 2015. Konsumsi Ikan Masih Rendah. Kementerian Kelautan dan Perikanan. Jakarta

Koesharyani I, Gardenia L, Widowati Z, Khumaira, dan Rustianti D.2018. Studi Kasus Infeksi Tilapia Lake Virus (TiLV) Pada Ikan Nila (Oreochromis Niloticus). Jurnal Riset Akuakultur, 13 (1) : 85-92

Kordi K, M. G.H. 1997. Budidaya Ikan Nila. Penerbit Dahara Prize, Semarang.

Lin, Y. and Y. Lin. 2016. Recent developments in the molecular detection of Fusarium oxysporum f. sp. cubense. Journal of Nature and Science 2 (10).

Lo, C.F., Chang, Y.S., Cheng, C.T., \& Kou, G.H. 1998. PCR monitoring of cultured shrimp for white spot syndrome virus (WSSV) infection in growout ponds. In Flegel, T.W. (Ed.). Advances in shrimp biotechnology. 01986

Nicholson, P., Fathi, M.A., Fischer, A., Mohan, C., Schieck, E., Mishra, N.,\& Jores,. (2017). Detection of Tilapia Lake Virus in Egyptian fish farms experiencing high mortalities in 2015. Short Comunication. Journal of Fish Disease, p. 1925- 1928; doi: 10.1111/jfd.12650.

Phaneuf, C. R., B. Mangadu, M. E. Piccini, A. K. Singh, and C. Koh. 2016. Rapid, porTabel, multiplexed detection of bacterial pathogens directly from clinical sample matrices. Biosensors 6 (49): 1-10.

Setiawan. 2012. Potensi Penggunaan Acepromazine Sebagai Alternatif Anestesi Ikan Nila (Oreochromis niloticus). Departemen Teknologi Hasil Perairan Fakultas Perikanan dan IImu Kelautan. Bogor: Institut Pertanian Bogor.

Sugiarto. 1988. Teknik Pembenihan Ikan Mujair dan Nila, Edisi I, C.V. Simplex Jakarta, $1-7$; 15-19.

Surachetpong W, Janetanakit T, Nonthabenjawan N, Tattiyapong P, Sirikanchana K andAmonsin A. 2017. Outbreaks of Tilapia Lake Virus infection, Thailand, 2015- 2016. Emerging Infectious Diseases 23:1031-33.global spread of the disease. Aquaculture, doi: 10.1016/ j.aquaculture.2017. 2017.06.035.

Swingle, H.S. 1961. Relationship of $p H$ of Pond Waters to Their Suitability for Fish Culture. Proc. Pacific Sci. Congress 9 (1957). 10: 72-75.

Tsofack JEK, Zamostianoa R, Wattedb S, Berkowitzb A, Rosenbluth E, Mishra N, Briese T, Lipkin WI, Kabuusud RM, Ferguson H et al. 2017. Detection of Tilapia Lake Virus (TiLV) in clinical samples by culturing and nested RTPCR. Journal of Clinical Microbiology 55:759-67.

Wardoyo, S. T. H. 1975. Pengelolaan Kualitas Air (Water Quality Management). Proyek Peningkatan Mutu Perguruan Tinggi. IPB, Bogor. 